\title{
KONSEP PENDIDIKAN ISLAM MENURUT KH. IMAM ZARKASYI
}

\author{
DWI BUDIMAN ASSIROJI
}

dwibudiman@gmail.com

Sekolah Tinggi Ilmu Da’wah Mohammad Natsir, Indonesia

\begin{abstract}
ABSTRAK
Tujuan penelitian: Tujuan penelitian ini adalah untuk mengungkap konsep pendidikan Islam menurut KH. Imam Zarkasyi. Metode penelitian: Kualitatif. Hasil penelitian : Konsep pendidikan Imam Zarkasyi bertumpu pada tujuan pendidikan yang ingin menjadikan anak didik bukan hanya memahami pelajaran, tapi lebih dari itu, mengamalkan dan menda'wahkannya. Untuk mencapai tujuan itu beliau membuat konsep pendidikan integral antara pelajaran agama dan pelajaran umum. Semua pelajaran itu kemudian diajarkan dengan menggunakan metode mengajar yang disusunya berdasarkan pengalaman dan buku-buku yang pernah dibacanya. Sehingga proses belajar mengajar berjalan baik dan menghasilkan para kader penerus yang memang disiapkan betul oleh Imam Zarkasyi untuk meneruskan perjuangannya. Dengan semua kelebihannya itu, Imam Zarkasyi berhasil membangun sebuah lembaga pendidikan yang telah terbukti memberikan kontribusi besar dalam perkembangan pendidikan Islam di Indonesia.
\end{abstract}

Kata kunci : Konsep, pendidikan Islam, Imam Zarkasyi

\section{PENDAHULUAN}

Pesantren adalah lembaga pendidikan Islam tertua di Indonesia, sehingga ada yang menyebut pesantren sebagai bapak pendidikan Islam Indonesia. Pesantren juga adalah lembaga pendidikan Islam yang sangat khas Indonesia. Sebab lembaga pendidikan yang mirip pesantren tidak ditemukan di kawasan Timur Tengah. ${ }^{1}$

Dalam perjalanan sejarahnya, pesantren telah membuktikan diri sebagai lembaga pendidikan yang memberikan banyak sekali kontribusi untuk masyarakat dan bangsa Indonesia. Dalam menghadapi penjajahan misalnya, pesantren adalah

${ }^{1}$ Abuddin Nata (ed), Sejarah Pertumbuhan dan Perkembangan Lembaga-lembaga Pendidikan Islam di Indonesia, Jakarta: Grasindo, 2001, hal. 89. (Pendapat senada diungkapkan Ahmad Tafsir bahwa pesantren merupakan lembaga pendidikan Islam yang tertua di Indonesia, setelah tumah tangga. Lihat: Ahmad Tafsir, Ilmu Pendidikan Islami, Bandung: Remaja Rosda Karya, 2012, hal. 289.) 
salah satu unsur penting yang selalu mengobarkan perlawanan dan menyiapkan para santrinya untuk melawan penjajah. Sampai-sampai Mansur Suryanegara pernah mengatakan bahwa sulit mencari gerakan perlawanan terhadap penjajah di Indonesia yang bukan dilakukan oleh orang pesantren. ${ }^{2}$ Sehingga beberapa kiyai pesantren kemudian diangkat sebagai pahlawan nasional oleh pemerintah karena kontribusinya dalam melawan penjajah dan merebut kemerdekaan. KH. Noer Ali, KH. Abdul Halim, K.H. Hasjim Asjarie, dan K.H. Abdul Wahid Hasjim adalah contohnya. ${ }^{3}$

Dari pesantren juga banyak lahir tokoh-tokoh Islam yang kemudian menjadi tokoh nasional dan bahkan internasional. Di antaranya, H.M. Rasyidi (alumni Pondok Jamsaren, Menteri Agama RI pertama), Mohammad Natsir (alumni Pesantren Persis / Perdana Menteri NKRI pertama), KH. Imam Zarkasyi (alumni Jamsaren, anggota Dewan Perancang Nasional), KH. Idham Khalid (alumni Pesantren Gontor / wakil Perdana Menteri dan Ketua MPRS). ${ }^{4}$

Dalam perkembangannya, dikenal dua jenis pesantren, yaitu pesantren tradisional dan pesantren modern. Pesantren tradisional adalah pesantren yang hanya mengajarkan kitab Islam klasik. Sementara pesantren modern adalah pesantren yang selain mengajarkan kitab Islam klasik juga mengajarkan ilmu umum dengan membuka sekolah umum di lingkungan dan di bawah tanggung jawab pesantren. ${ }^{5}$

Salah satu pesantren modern yang berkembang sangat pesat hingga hari ini adalah Pondok Modern Darussalam yang berada di Gontor, Ponorogo. Sampai tahun 2012, pesantren yang didirikan pada tahun 1926 ini, telah memiliki 13 pesantren putra dan tujuh pesantren putri yang tersebar di beberapa wilayah di Indonesia. Jumlah santri dan guru di semua pesantren yang lebih dikenal dengan nama Pesantren Gontor ini adalah 24.145 orang. Dengan tanah wakaf seluas 727,37 Ha. Pesantren ini juga sudah berhasil mengembangkan jenjang pendidikannya hingga tingkat master (S.2). ${ }^{6}$

Perkembangan pesantren Gontor yang begitu pesat tidak dapat dilepaskan dari sosok salah seorang pendirinya yaitu Imam Zarkasyi. Ia merupakan pendiri yang lebih banyak dikenal oleh masyarakat dibandingkan kedua kakaknya yang sama-sama mendirikan Pesantren Gontor. Selain karena usianya lebih panjang dari kedua kakaknya, juga karena Imam Zarkasyi memiliki

${ }^{2}$ Ahmad Tafsir, Ilmu Pendidikan Islami, Bandung: Remaja Rosda Karya, 2012, hal. 290.

${ }^{3}$ http://www.kemsos.go.id, DAFTAR NAMA PAHLAWAN NASIONAL REPUBLIK INDONESIA, (Jum'at, 26 April 2013)

${ }^{4}$ http://www.majalahgontor.net, Membaca Ulang Kontribusi Pesantren terhadap Bangsa, Jum'at, 26 April 2013.

${ }^{5}$ Ahmad Tafsir, Ilmu Pendidikan Islami, hal. 293.

${ }^{6}$ Jurnal Tahunan Wardun, Sambutan Pimpinan, Ponorogo: Darussalam Press, 2012, hal.ix.

34|Jurnal Dakwah|Vol.1 No.1|2018 
pemikiran pendidikan yang kemudian banyak ia implementasikan di Pesantren Gontor.

Karena itu, mengkaji pemikiran pendidikan Imam Zarkasyi, khususnya yang berkaitan dengan Pesantren, menjadi sangat menarik. Dalam makalah ini akan dibahas pemikiran pendidikannya dengan didahului oleh penjelasan tentang biografi singkatnya. Selanjutnya dibahas faktor yang dinilai mempengaruhi pemikiran pendidikannya. Kemudian baru dibahas pemikiran pendidikannya yang terdiri atas tujuan pendidikan, integrasi ilmu dan sistem pendidikan, metode mengajar, metode pembelajaran bahasa Arab, modernisasi pesantren dan terakhir konsep kaderisasinya.

\section{Biografi Singkat}

Imam Zarkasyi dilahirkan pada tanggl 21 Maret 1910 di desa Gontor, Ponorogo, Jawa Timur. Ia adalah anak ketujuh dari Kyai Santoso Anom Besari, generasi ketiga yang memimpin Pesantren Gontor Lama ${ }^{7}$. Saat usia Imam Zarkasyi delapan tahun, ayahnya meninggal dunia. Dua tahun kemudian, tepatnya tahun 1920, ibunya juga meninggal. ${ }^{8}$

Sekali pun sudah ditinggal kedua orangtuanya, namun pendidikan Imam Zarkasyi tetap berlanjut. Bahkan ia berkesempatan mengenyam pendidikan di dua model lembaga pendidikan, di pesantren tradisional dan di pendidikan madrasah yang bercorak modern saat itu.

Di tingkat dasar, Imam Zarkasyi belajar di Sekolah Dasar Ongko Loro di Jetis Ponorogo. Berbarengan dengan itu ia juga mondok di Pondok Pesantren Josari, Ponorogo. Imam Zarkasyi pernah pula belajar di pondok Joresan Ponorogo. Selesai belajar di Sekolah Ongko Loro, beliau melanjutkan belajar ke Pondok Pesantren Jamsaren, Solo sekaligus belajar di Sekolah Mambaul 'Ulum dan kemudian melanjutkan ke Madrasah Adabiyah dibawah asuhan Ustadz alHasyimi ${ }^{9}$. Selama belajar di Madrasah Adabiyah ini, Imam Zarkasyi sangat tertarik dengan pelajaran Bahasa Arab dan berusaha mendalaminya. Sang Guru, Ustadz al-Hasyimi, juga sangat mempengaruhi pemikiran Imam Zarkasyi, terutama mengenai modernisasi sistem pendidikan Islam.

Setamat dari Jamsaren dan sekolah Madrasah Adabiyah pada tahun 1930, Imam Zarkasyi melanjutkan pendidikannya di Normal Islam dan Sumatera

7 Disebut Gontor Lama, karena Pesantren ini kemudian mati suri dan kembali dihidupkan oleh ketiga putra beliau - Ahmad Sahal, Zainuddin Fanani dan Imam Zarkasyi- dengan diberi nama Gontor Baru, walau kemudian lebih dikenal dengan Pesantren Gontor.

${ }^{8}$ https://id.wikipedia.org, Pondok Modern Darussalam Gontor, 10 April 2013.

${ }^{9}$ Seorang ulama, tokoh politik dan sastrawan asal Tunisia yang diasingkan oleh Penjajah Perancis dari negerinya. Ia kemudian menetap di Solo. 
Thawalib di Padang Panjang, Sumatera Barat. Lembaga ini dipimpin oleh Mahmud Yunus, seorang alumni Darul 'Ulum, Mesir. Imam Zarkasyi menyelesaikan pendidikannya di sekolah ini tahun $1935 .{ }^{10}$ Selepas itu ia diamanahi oleh Mahmud Yunus untuk menjadi guru dan direktur di almamaternya. Sebab dalam pandangan Mahmud Yunus, Imam Zarkasyi memiliki kemampuan untuk mengelola lembaga pendidikan dan sekaligus mengajar. Setahun kemudian, Imam Zarkasyi mengembalikan amanah gurunya itu dan kembali ke Gontor untuk bergabung kembali bersama kedua kakaknya, Zainuddin Fannani dan Ahmad Sahal, mengelola Pesantren Gontor. Imam Zarkasyi melihat, kehadirannya lebih diperlukan di Gontor daripada di Padang Panjang. ${ }^{11}$

Sebab saat itu, Pesantren Gontor sendiri baru kembali bangkit setelah mati suri sekian lama. Tepatnya pada tanggal 20 September 1926 bertepatan dengan 12 Rabi'ul Awwal 1345 H., pada peringatan Maulid Nabi, di hadapan masyarakat yang hadir pada kesempatan itu, dideklarasikan pembukaan kembali Pondok Gontor oleh tiga bersaudara, Imam Zarkasyi, Zainuddin Fanani dan Ahmad Sahal. ${ }^{12}$ Mereka memperbaharui sistem pendidikan di Gontor dan menamakannya dengan Pondok Modern Darussalam Gontor. Jenjang pendidikan dasar dimulai dengan nama Tarbiyatul Athfal. ${ }^{13}$

Setelah bergabung kembali mengelola Gontor, Imam Zarkasyi mengusulkan kepada kedua kakaknya untuk membuka program baru yang diberi nama Kulliyatul Mu'allimin al-Islamiyah (KMI), program pendidikan yang diselenggarakan selama enam tahun, setingkat dengan jenjang pendidikan menengah. Usulnya itu disetujui dan ia diamanahi menjadi direkturnya. Gagasannya ini dipengaruhi oleh pendidikannya ketika di Normal Islam School, Padang Panjang. ${ }^{14}$ Di Pesantren Gontor, Imam Zarkasyi juga pernah diamanahi Pejabat Rektor Institut Pendidikan Darussalam (IPD) hingga berpulang ke rabmatullah pada tahun 1985.

Selain mengelola Pesantren Gontor, Imam Zarkasyi juga diberikan beberapa amanah di luar pesantren. Diantaranya ia pernah menjadi Kepala Kantor Agama Karesidenan Madiun. Di Kementrian Agama, Imam Zarkasyi diangkat menjadi Seksi Pendidikan. Kemudian menjadi Kepala Bagian Perencanaan Pendidikan Agama pada sekolah dasar tahun 1951-1953 dan Kepala Dewan Pengawas Pendidikan Agama pada tahun 1953. Pada Kementrian Pendidikan ia sempat menjadi anggota Badan Perencanaan Peraturan Pokok Pendidikan Swasta tahun 1957. Pernah pula dipercaya menjadi ketua Majelis Pertimbangan Pendidikan dan Pengajaran Agama (MP3A) hingga wafatnya. Dan

10 http://insistnet.com, Rabu, 10 April 2013 lihat juga https://id.wikipedia.org, Pondok Modern Darussalam Gontor, 10 April 2013.

${ }^{11}$ Abuddin Nata, Tokoh-tokoh Pembaharuan Pendidikan Islam di Indonesia, Jakarta: Raja Grafindo Persada, 2005, hal.198.

12 http://gontor.ac.id, berdirinya-pondok-gontor, 10 April 2013.

${ }_{13} \mathrm{http://gontor.ac.id}$, latar-belakang, 10 April 2013.

${ }_{14}$ Abuddin Nata, Tokoh-tokoh Pembaharuan ..., hal.198. 
sejak tahun 1948-1955 menjadi ketua PB Persatuan Guru Islam Indonesia (PGII), selanjutnya tetap menjadi penasehat hinga akhir hayatnya.

Selain itu, pada tahun 1959 Imam Zarkasyi diangkat oleh Presiden Soekarno menjadi anggota Dewan Perancang Nasional (Deppernas). Disamping itu juga menjadi Dewan Pertimbangan Majelis Ulama Indonesia (MUI) Pusat. ${ }^{15}$

Di kancah Internasional Imam Zarkasyi pernah menjadi Anggota Delegasi Indonesia dalam peninjauan ke negara-negara Uni Sovyet tahun 1962 dan menjadi wakil Indonesia dalam Mu'tamar Majma' al-Bubuts al-Islamiyah (Muktamar Akademi Islam se Dunia) ke VII di Kairo, Mesir tahun 1972.

Pada tanggal 30 April 1985 pukul 21.00 WIB beliau meninggal dunia di Rumah Sakit Umum Madiun dengan meninggalkan seorang Isteri dan 11 orang anak. Anak-anak Imam Zarkasyi adalah:

1. KH. Abdullah Syukri Zarkasyi, MA.

2. Siti Khuriyyah Subakir

3. Dra. Siti Rosyidah

4. Drs. Amal Fathullah Zarkasyi, MA.

5. Dra. Hj. Annisah Fatimah Tijani

6. Siti Farid Ismail

7. Dra. Maimunah Alamsyah

8. Dr. Ahmad Hidayatullah Zarkasyi, MA.

9. Dr. Hamid Fahmi Zarkasyi, MA.

10. Drs. Nasrullah Zainul Muttaqin

11. Ir. Muhammada Ridho, MM. ${ }^{16}$

\section{Karya Tulis}

Imam Zarkasyi merupakan seorang tokoh yang cukup produktif menulis. Dari sekian banyak tulisannya, ada yang ditulis sendiri ada juga yang ditulis bersama orang lain. Beberapa buku hasil karyanya adalah:

1. Senjata Penganjur

2. Pedoman Pendidikan Modern

3. Kursus bahasa Islam (Ditulis bersama KH Zainuddin Fanani)

4. Ushuluddin (Pelajaran 'Aqaid/Keimanan)

5. Pelajaran Fiqh I dan II

6. Pelajaran Tajwid

7. Bimbingan Keimanan

8. Qowa'idul Imla'

9. Pelajaran Huruf Al Qur'an I dan II

${ }^{15}$ Ibid, hal.199.

${ }^{16}$ https://id.wikipedia.org, Pondok Modern Darussalam Gontor, 10 April 2013. 
10. Pelajaran Bahasa Arab I dan II (serta Kamusnya)

11. At-tamrinat jilid I, II, III (beserta kamusnya)

12. I'rabu Amtsilati-Al Jumal, jilid I \& II. ${ }^{17}$

Dari pemaparan biografi Imam Zarkasyi di atas, dapat ditarik kesimpulan bahwa beliau adalah orang yang banyak menghabiskan umurnya di dunia pendidikan. Disamping itu, kegiatannya di pemerintahan maupun organisasi juga berkaitan erat dengan dunia pendidikan. Tulisan yang dihasilkannya pun demikian, banyak yang terkait dengan dunia pendidikan, baik tentang bahan ajar maupun tata cara mengajar. Dengan demikian beliau dapat dikatakan sebagai tokoh pendidikan. ${ }^{18}$ Karena itu dibawah ini akan diulas mengenai pemikiran pendidikan Imam Zarkasyi, dengan didahului oleh pembahasan tentang faktor-faktor yang mempengaruhi pemikiran pendidikannya.

\section{Faktor-Faktor Yang Mempengaruhi Pemikiran Pendidikan Imam Zarkasyi}

Sebelum membahas mengenai pemikiran pendidikan Imam Zarkasyi, akan dibahas terlebih dahulu faktor-faktor yang mempengaruhi pemikiran pendidikannya.

Faktor eksternal yang sangat mempengaruhi pemikiran pendidikan Imam Zarkasyi adalah karena ia berkesempatan mengenyam pendidikan di lembaga pendidikan yang beragam, mulai dari pesantren yang tradisional hingga lembaga pendidikan modern semacam Sekolah Noormal Islam di Padang Panjang. Dari sekian banyak lembaga pendidikan itu, Sekolah Noormal Islam adalah yang paling besar pengaruhnya terhadap pemikiran pendidikan Imam Zarkasyi, terutama dari sosok Mahmud Yunus. Ada dua hal yang diambil Imam Zarkasyi dari sekolah pimpinan Mahmud Yunus ini. Pertama, keyakinannya bahwa jalur yang paling pas untuk melakukan gerakan pembaruan dan kebangkitan Islam di masyarakat adalah jalur pendidikan bukan jalur politik. Sebagaimana ucapannya, "Politik saya adalah politik pendidikan". ${ }^{19}$ Kedua, pendidikan Islam di Indonesia harus diperbaharui agar sesuai dengan perkembangan zaman dan tantangan yang muncul.

Menurut putra tertuanya, Abdullah Syukri Zarkasyi, kedua prinsip itu berasal dari pemikiran Muhammad Abduh, tokoh yang sangat mempengaruhi perkembangan pendidikan Islam di Pandang Panjang, termasuk kepada Mahmud Yunus. Sebab Mahmud Yunus adalah salah seorang alumni dari perguruan tinggi

17 Ibid

${ }^{18}$ Kepakaran Imam Zarkasyi diakui oleh banyak orang, diantaranya oleh Abuddin Nata (lihat Abuddin Nata, Tokoh-tokoh Pembaharuan Pendidikan Islam di Indonesia, Jakarta: Raja Grafindo Persada, 2005, hal.200).

${ }^{19}$ http://insistnet.com, Rabu, 10 April 2013. 
Daar al-Uluum, sebuah lembaga pendidikan hasil dari pemikiran Abduh tentang pembaruan sistem pendidikan. ${ }^{20}$

Namun demikian, Imam Zarkasyi tidak mengkopi begitu saja pemikiran Mahmud Yunus di Noormal Islam dan kemudian mengimplementasikannya di Pesantren Gontor. Sebab menurut Abdullah Syukri, pemikiran Imam Zarkasyi dipengaruhi juga oleh al-Hasyimi, gurunya di Madrasah Arabiyah Islamiyah, Solo yang berasal dari Tunisia. Dari gurunya ini Imam Zarkasyi terutama mendapat pemikiran tentang urgensi bahasa Arab dan cara pengajarannya. ${ }^{21}$

Saat itu, pemikiran tentang modernisasi pendidikan Islam semacam ini bertujuan untuk menggunakan sektor pendidikan sebagai wahana pembaharuan ideologi dan budaya Islam sekaligus juga sebagai cara untuk menjawab tantangan budaya Barat, dominasi kolonial dan sistem tehnologi Barat yang kapitalistis. ${ }^{22}$

\section{HASIL DAN DISKUSI}

\section{Pemikiran Pendidikan Imam Zarkasyi}

\section{Tujuan Pendidikan}

Imam Zarkasyi berpendapat bahwa tujuan pendidikan bukan hanya membuat anak didik pintar atau memiliki banyak ilmu. Tetapi lebih dari itu, tujuan sebenarnya dari pendidikan adalah bagaimana agar ilmu yang dimiliki oleh anak didik dapat diamalkan dan disampaikannya kepada orang lain. ${ }^{23}$ Pendapat Imam Zarkasyi ini sesuai dengan prinsip dalam Islam. Dimana dalam Islam dikenal ada tiga kewajiban yang harus dikerjakan oleh setiap muslim, yaitu mencari ilmu, mengamalkan ilmu dan kemudian menda'wahkan ilmu yang sudah dimiliki dan diamalkannya itu. ${ }^{24}$

Sehingga tak heran kalau kemudian, Imam Zarkasyi tidak mengarahkan anak-anak didiknya untuk menjadi pengusaha, pegawai, pejabat, dan bahkan kyai. Ia justru mengarahkan santrinya untuk menjadi manusia seutuhnya. Dalam arti manusia yang memiliki ilmu, mengamalkan ilmu dan sekaligus menda'wahkan ilmunya itu, apapun kelak profesi yang dijalaninya. ${ }^{25}$ Tujuan pendidikan Imam

20 Abdullah Syukri Zarkasyi, Gontor \& Pembaharuan Pendidikan Pesantren, Jakarta: Raja Grafindo Persada, 2006, hal.114.

${ }^{21}$ Ibid

${ }^{22}$ Manfred Ziemek, Pesantren dalam Perubahan Sosial (terj), Jakarta: P3M, 1986, Hal. 91.

${ }^{23}$ Abuddin Nata, Tokoh-tokoh Pembaharuan ..., hal.201.

${ }^{24}$ Misalnya sebagaimana yang dijelaskan oleh Syaikh Muhammad Ibn Abdil Wahhab bahwa berdasarkan surat al-'Ashr, ada empat kewajiban pokok bagi seorang muslim, yaitu mencari ilmu, mengamalkan ilmu, menda'wahkan ilmu dan bersabar dalam menjalankannya. (lihat Abdurrahman An-Najdi, Hasyiyah Tsalatsah al-Ushul, 1987, hal. 10-12)

25 (http://insistnet.com, Rabu, 10 April 2013. 
Zarkasyi ini dimaksudkan agar kelak anak-anak didiknya menjadi manusia yang siap memasuki kehidupan di masyarakat. Ia menjelaskan:

"Yang jelas hanya satu saja, yaitu untuk menjadi orang ... Jadi masih bersifat umum dan belum menjurus, belum calon doktor, belum calon kusir, belum calon apa-apa. Katakanlah calon manusia, manusia apa kerjanya? Dari pendidikan yang kami berikan itu mereka akan tahu nanti di masyarakat apa yang akan dikerjakan ... jadi persiapan untuk masuk masyarakat dan bukan untuk masuk Perguruan Tinggi, maka dari itu kami namai pendidikannya, pendidikan kemasyarakatan, dan itu yang kami utamakan". ${ }^{26}$

Dengan kata lain Imam Zarkasyi menginginkan anak-anak didiknya kelak dapat ikut serta secara aktif dalam proses perubahan sosial dan pembangunan masyarakat dalam rangka mengikuti perkembangan kemajuan ilmu pengetahuan dan teknologi modern. ${ }^{27}$

Walaupun demikian, bukan berarti Imam Zarkasyi melarang anak-anak didiknya melanjutkan pendidikan ke Perguruan Tinggi. Bahkan sebaliknya ia mendorong mereka untuk terus belajar sampai batas kemampuannya. Ia menyatakan:

"Hanya saja, setelah kita tamat dan ternyata masih kuat, semangat masih ada, orang tua masih sanggup, persiapan orak masih segar dan tidak/belum terpengaruh "ingin lekas tua", dapat juga mencoba masuk Perguruan Tinggi di dalam dan luar negeri, dan banyak pula yang telah mencapai kesarjanaannya atau menyelesaikan studinya." 28

Maka tak heran jika semua anak Imam Zarkasyi melanjutkan pendidikan mereka ke perguruan tinggi. Bahkan kemudian Pesantren Gontor sendiri mendirikan lembaga pendidikan setingkat perguruan tinggi yang awalnya diberi nama Institut Pendidikan Darussalam (IPD) dan kemudian dirubah menjadi Institut Studi Islam Darussalam (ISID). Yang menjadi rektor pertama lembaga ini adalah Imam Zarkasyi sendiri. ${ }^{29}$

\section{Pendidikan Integral}

26 Jajat Burhanuddin dan Ahmad Baedowi dalam Abuddin Nata, Tokoh-tokoh Pembaharuan ..., hal.205.

${ }^{27}$ Manfred Ziemek, Pesantren dalam Perubahan Sosial, hal. 158.

28 Jajat Burhanuddin dan Ahmad Baedowi dalam Abuddin Nata, Tokoh-tokoh Pembaharuan ..., hal.206.

${ }^{29}$ Tim Penyusun, Profil ISID, Ponorogo: Darussalam University Press, 2011, hal.13. 
Sejak awal, Imam Zarkasyi sudah memiliki konsep pendidikan integral. Bermula dari keprihatinan Ahmad Sahal, kakak tertuanya, setelah pada tahun 1926 mengikuti Kongres Umat Islam pertama di Surabaya. Dalam kongres itu disepakati bahwa umat Islam Indonesia akan mengirim utusan guna mengikuti Muktamar Islam se-Dunia yang akan diselenggarakn di Makkah. Namun muncul kesulitan mengenai siapa orang yang akan diutus, sebab salah satu syaratnya orang tersebut harus memiliki kemampuan bahasa Arab dan bahasa Inggris sama baiknya. Karena tidak ada satu orang pun yang memiliki kemampuan dua bahasa itu maka diutuslah dua orang, yaitu HOS. Cokroaminoto yang pandai berbahas Inggris dan Kiai Mas Mansur yang fasih berbahasa Arab.

Keprihatinanya itu kemudian ia diskusikan dengan kedua adiknya, Zainuddin Fananie dan Imam Zarkasyi. Mereka bertiga kemudian menyimpulkan bahwa semua itu disebabkan karena terjadinya pemisahan pendidikan, antara pendidikan agama yang identik dengan bahasa Arab dan pendidikan umum yang identik dengan bahasa Inggris. Pendidikan dikotomis semacam ini kemudian menghasilkan orang-orang yang hanya menguasai ilmu agama dan bahasa arab saja atau menguasai ilmu umum dan bahasa Inggris saja.

Akhirnya mereka bertiga sepakat untuk menghapuskan dikotomi ilmu semacam itu dengan mendirikan lembaga pendidikan yang integral. Sebuah lembaga pendidikan yang mengintegrasikan ilmu agama dengan ilmu umum. Untuk mewujudkannya mereka kemudian memilih sistem pendidikan pesantren yang mereka integrasikan dengan sistem pendidikan madrasah/sekolah. Mereka bertiga kemudian sering mengatakan bahwa Pesantren Gontor bertujuan menghasilkan "ulama yang intelek". ${ }^{30}$ Bisa jadi karena itulah kemudian Imam Zarkasyi memilih untuk menempuh pendidikan di dua model sistem pendidikan, di pesantren dan di madrasah/sekolah.

Prinsip Imam Zarkasyi ini juga terlihat dari jawabannya ketika ditanya oleh Presiden Soeharto dalam kunjungannya ke Pesantren Gontor. Soeharto bertanya tentang prosentase pelajaran agama dan pelajaran umum di Pesantren Gontor, Imam Zarkasyi menjawab dengan tegas: "100\% agama dan 100\% umum". Maksud sebenarnya tidak ada prosentasi agama dan umum di pesantrennya. Sebab dalam Islam semua ilmu adalah sama. Hanya bedanya yang satu dihasilkan dari telaah terhadap al-Quran dan as-Sunnah, sementara yang satu adalah hasil dari penelitian terhadap alam raya.

\section{Metode pembelajaran}

Metode pembelajaran menurut Imam Zarkasyi tergambar dalam buku yang ditulisnya dengan judul Pedoman dan Arah Tiap-Tiap Pelajaran di Tiap-Tiap Kelas. Abdullah Syukri Zarkasyi, dari buku tersebut menyimpulkan bahwa metode pembelajaran menurut Imam Zarkasyi adalah ${ }^{31}$ :

30 Abdullah Syukri Zarkasyi, Gontor \& Pembaharuan Pendidikan Pesantren, hal.110-112.

${ }^{31}$ Ibid, hal. 152. 
a. Pelajaran harus dimulai dari yang mudah dan sederhana.

b. Tidak tergesa-gesa pindah ke pelajaran yang lain sebelum siswa memahami betul pelajaran yang telah diberikan.

c. Proses pengajaran harus teratur dan sistemik.

d. Latihan-latihan diperbanyak setelah pelajaran selesai.

e. Guru tidak boleh bosan mengulangi pelajaran dengan soal-soal evaluasi.

f. Guru hendaknya pandai-pandai dalam mengetahui dan mengukur kemampuan dan kondisi kepribadian siswa.

g. Guru hendaknya pandai menarik perhatian siswa dengan latihanlatihan dan ulangan-ulangan yang bervariasi.

h. Guru hendaknya selalu memotivasi siswa yang pandai dan tidak meremehkan siswa yang lemah.

i. Guru hendaknya memperhatikan tingkat perbedaan kecerdasan dan kelemahan individu siswa.

Dari penjelasan di atas nampak jelas bahwa Imam Zarkasyi adalah seorang pendidik yang sangat memahami metode mengajar yang baik. Sebab metode yag dikemukakannya merupakan gabungan antara pemahaman yang baik terhadap pola pengajaran dan pemahaman terhadap kondisi anak didik.

\section{Metode Pengajaran Bahasa Arab}

Kemampuan berbahasa Arab merupakan salah satu ciri khas lulusan pesantren Gontor. Ini tidak lepas dari kesungguhan Pesantren Gontor dalam mengajarakan bahasa Arab kepada para santrinya. Salah satu kunci keberhasilan pengajaran bahasa Arab di Pesantren Gontor terletak pada metode pengajarannya. Imam Zarkasyi memiliki metode yang baik dalam mengajarkan bahasa Arab, di bawah ini penjelasannya.

Dalam metode pengajaran bahasa Arab, Imam Zarkasyi berpendapat bahwa yang penting adalah memperbanyak lathan. Karenanya guru bahasa Arab tidak boleh menggunakan sistem terjemahan. Melainkan harus lebih memperbanyak latihan, baik lisan maupun tulisan. Sehingga murid diharapkan memiliki kemampuan untuk memfungsikan satu kata dalam banyak ragam kalimat. Petuah Imam Zarkasyi yang terkenal dalam hal ini adalah, "al-Kalimah waahidah fi alfi jumlah khairun min alfi kalimah fi jumlatin waahidah". Maksudnya adalah, memahami satu kata dan mampu menempatkannya dalam banyak kalimat adalah lebih baik dari pada mengetahui banyak kata tapi hanya dapat menerapankan masing-masing kata itu dalam satu kalimat saja. ${ }^{32}$ Model pembelajaran bahasa seperti ini sesuai dengan teori-teori pengajaran bahasa yang lebih menekankan dan memperbanyak praktek daripada hanya sekedar teori.

${ }^{32}$ Ibid, hal. 149.

42 | Jurnal Dakwah | Vol.1 No.1|2018 
Model pengajaran bahasa Arab seperti ini diakui keberhasilanya oleh banyak pihak, salah satunya oleh Prof. Zakiyah Daradjat. Ia mengatakan:

"Saya telah banyak mengunjungi pesantren-pesantren yang didirikan oleh alumni-alumni Gontor... saya kira pesantren itu sangat baik. Bahasa Arab dan Inggris para santri aktif, dan itu sangat bagus. Itu adalah impian kita dari dulu... di Gontor dan di pesantren-pesantren yang didirikan oleh alumni-alumni Gontor, hal itu sudah berjalan dengan baik. Jadi beliau (Pak Zarkasyi, salah seorang pendiri Pondok Gontor) sudah berhasil." 33

\section{Modernisasi Pesantren}

Di masa lalu, pesantren sering diidentikan orang sebagai lembaga pendidikan yang tidak terurus dengan baik. hal ini mendorong Imam Zarkasyi untuk melakukan gerakan modernisasi pesantren. Langkah awal untuk menu kea rah itu adalah dengan melakukan studi banding ke empat tempat yang berbeda. Yaitu ke Universitas al-Azhar, Mesir, ke Pondok Syanggit di Libya, ke Universitas Muslim Aligarch dan ke Perguruan Shantiniketan. ${ }^{34}$

Langkah lain yang diambil dalam rangka memodernisasi pesantren adalah dengan mewakafkan pesantren. Imam Zarkasyi dan kedua kakaknya mewakafkan Pesantren Gontor kepada umat Islam. sehingga Pesantren Gontor tidak lagi milik keluarga, melainkan sudah menjadi milik umat Islam. Momen bersejarah bagi terwujudnya niat mewakafkan Pondok kepada Ummat Islam terjadi pada Peringatan Empat Windu Pondok Modern Darussalam Gontor. Tepatnya pada tanggal 12 Oktober 1958, Trimurti (K.H. Ahmad Sahal, K.H. Zainuddin Fannani, dan K.H. Imam Zarkarsyi) sebagai pendiri Pondok mewakafkan Pondok Modern Darussalam Gontor kepada IKPM yang diwakili oleh 15 orang. Wakaf Pondok Modern Darussalam Gontor ketika itu terdiri dari tanah kering seluas 1,740 ha (Kampus Pondok), tanah basah seluas 16,851 ha, dan gedung sebanyak 12 buah; Masjid, Madrasah, Indonesia I, Indonesia II, Indonesia III, Tunis, Gedung Baru, Abadi, Asia Baru, PSA, BPPM, dan Darul Kutub. ${ }^{35}$

\section{Kaderisasi}

Salah satu kunci keberhasilan Pesantren Gontor dapat terus berkembang hingga kini adalah proses kaderisasi yang berjalan baik di sana. $\mathrm{Hal}$

33 Zakiyah Daradjat dalam Abdullah Syukri Zarkasyi, Gontor \& Pembaharuan Pendidikan Pesantren, hal. 169.

${ }^{34}$ Abuddin Nata, Tokoh-tokoh Pembaharuan ..., hal.207.

${ }^{35}$ http://gontor.ac.id, kepemimpinan-generasi-pertama, 10 April 2013. 
ini tidak lepas dari peran Imam Zarkasyi yang sangat memperhatikan proses kaderisasi. Sebagaimana kesaksian putra tertuanya, Abdullah Syukri, suatu hari ia pernah dipanggil oleh sang ayah bersama sepupunya Hasan Abdullah. Kemudian Imam Zarkasyi berkata kepada keduanya, "Syukri, kamu anak saya, Hasan kamu anaknya Pak Sahal, pegang jiwa dan filsafat pondok, kalau tidak kamu akan terpental dari pondok."

Dalam pandangan Abdullah Syukri, perkataan ayahnya itu menggambarkan bahwa bertahannya seorang kader Pesantren Gontor di sana bukan didasarkan kepada keturunan, melainkan bergantung kepada dirinya sendiri. Jika ia tetap memegang teguh jiwa dan filsafat pondok maka ia akan bertahan, jika tidak maka ia akan terpental. Hal ini juga berlaku bagi anak-anak para pendiri Pesantren Gontor. ${ }^{36}$

Dengan demikian, proses kaderisasi yang dilakukan Imam Zarkasyi tidak didasarkan pada keturunan sebagaimana kebiasaan kebanyakan pesantren saat itu, tapi berdasarkan kapasitas diri masing-masing orang. Sehingga Pesantren Gontor dapat terus dipimpin oleh orang yang memang memiliki kemampuan sebagaoi seorang pemimpin.

\section{KESIMPULAN}

Imam Zarkasyi adalah seorang tokoh pendidikan Islam yang memiliki kemampuan komplit. Ia adalah seorang pemikir pendidikan yang menghasilkan banyak sekali konsep pendidikan. Ia juga seorang konseptor yang mampu membuat konsep untuk sebuah kegiatan pendidikan. Ia sekaligus juga seorang praktisi pendidikan yang langsung mengimplementasikan pemikiran dan konsepnya tentang pendidikan dalam kegiatan belajar-mengajar yang dilakukannya di Pesantren Gontor.

Konsep pendidikan Imam Zarkasyi bertumpu pada tujuan pendidikan yang ingin menjadikan anak didik bukan hanya memahami pelajaran, tapi lebih dari itu, mengamalkan dan menda'wahkannya. Untuk mencapai tujuan itu beliau membuat konsep pendidikan integral antara pelajaran agama dan pelajaran umum. Semua pelajaran itu kemudian diajarkan dengan menggunakan metode mengajar yang disusunya berdasarkan pengalaman dan buku-buku yang pernah dibacanya. Sehingga proses belajar mengajar berjalan baik dan menghasilkan para kader penerus yang memang disiapkan betul oleh Imam Zarkasyi untuk meneruskan perjuangannya.

36 Abdullah Syukri Zarkasyi, Bekal untuk Memimpin, Ponorogo: Trimurti Press, 2011, hal. 67. 
Dengan semua kelebihannya itu, Imam Zarkasyi berhasil membangun sebuah lembaga pendidikan yang telah terbukti memberikan kontribusi besar dalam perkembangan pendidikan Islam di Indonesia.

\section{DAFTAR PUSTAKA}


An-Najdi, Abdurrahman, Hasyiyah Tsalatsah al-Ushul, 1987

Nata, Abuddin, Sejarah Pertumbuhan dan Perkembangan Lembaga-lembaga Pendidikan Islam di Indonesia, Jakarta: Grasindo, 2001.

, Tokoh-tokoh Pembaharuan Pendidikan Islam di Indonesia, Jakarta: Raja Grafindo Persada, 2005.

Syukri Zarkasyi, Abdullah, Bekal untuk Memimpin, Ponorogo: Trimurti Press, 2011

---------------, Gontor \& Pembaharuan Pendidikan Pesantren, Jakarta: Raja Grafindo Persada, 2006, hal.114.

Tafsir, Ahmad, Ilmu Pendidikan Islami, Bandung: Remaja Rosda Karya, 2012

Ziemek, Manfred, Pesantren dalam Perubahan Sosial (terj), Jakarta: P3M, 1986.

Jurnal Tahunan Wardun, Sambutan Pimpinan, Ponorogo: Darussalam Press, 2012. Tim Penyusun, Profil ISID, Ponorogo: Darussalam University Press, 2011.

\section{Daftar Website :}

http://gontor.ac.id, berdirinya-pondok-gontor, 10 April 2013.

http://www.kemsos.go.id, DAFTAR NAMA PAHLAWAN NASIONAL REPUBLIK INDONESIA, Jum'at, 26 April 2013.

http:/ /www.majalahgontor.net, Membaca Ulang Kontribusi Pesantren terhadap Bangsa, Jum'at, 26 April 2013.

http://insistnet.com, Rabu, 10 April 2013.

https://id.wikipedia.org, Pondok Modern Darussalam Gontor, 10 April 2013. 